\title{
The Effect of Corruption on International Trade: A Case Study of Indonesian Trade to Nine Countries
}

\author{
By: \\ Danang Ibnu Atsir ${ }^{1)}$, Sunaryati ${ }^{2)}$ \\ ${ }^{1,2)}$ Faculty of Economics and Islamic Business, UIN Sunan Kalijaga Yogyakarta \\ ${ }^{1)}$ Email: ibnuatsirdanang@gmail.com
}

\begin{abstract}
Corruption is a form of abuse of ethical authority by public officials, which is divided into two parts: bribery and forced collection. The effect of corruption like bribes and illegal levies is widespread in the public sector. One interesting investigation is the effect of corruption on international trade. Corruption becomes a barrier in international trade, where corruption plays a role in the access of trade goods and services from within and abroad. Using the gravity model, the focus of this research was the effect of corruption on international trade by taking a case study of Indonesia's bilateral trade with its nine largest export destination countries. Using panel data, analysis tools used in this research were common effect, fixed effect, random effect and poisson pseudo maximum likelihood (PPML). In this research, it was found that geographical distance variable in its fixed units caused the omitted variable so that the error term correlated with independent variables. In order to overcome the problem, poisson pseudo maximum likelihood method was used in performing regression gravity model with linear log form, so the omitted variable issue on the geographical distance can be eliminated. The results of this research concluded that corruption played a role in international trade through bureaucratic mechanisms of trade and investment licensing and the effect of corruption was more detrimental to exporters.
\end{abstract}

Keywords: Gravity Model, Corruption, International Trade, Poisson Pseudo Maximum Likelihood (PPML).

\begin{abstract}
ABSTRAK
Korupsi adalah bentuk penyalahgunaan wewenang etis oleh pejabat publik, yang dibagi menjadi dua bagian: penyuapan dan pemaksaan paksa. Efek korupsi seperti suap dan pungutan liar tersebar luas di sektor publik. Salah satu investigasi yang menarik adalah efek korupsi pada perdagangan internasional. Korupsi menjadi penghalang dalam perdagangan internasional, di mana korupsi memainkan peran dalam akses barang dan jasa perdagangan dari dalam dan luar negeri. Dengan menggunakan model gravitasi, fokus penelitian ini adalah efek korupsi pada perdagangan internasional dengan mengambil studi kasus perdagangan bilateral Indonesia dengan sembilan negara tujuan ekspor terbesarnya. Menggunakan data panel, alat analisis yang digunakan dalam penelitian ini adalah efek umum, efek tetap, efek acak dan poisson pseudo maximum likelihood (PPML). Dalam penelitian ini, ditemukan bahwa variabel jarak geografis dalam unit tetapnya menyebabkan variabel dihilangkan sehingga istilah kesalahan berkorelasi dengan variabel independen. Untuk mengatasi masalah, metode probabilitas maksimum pseudo poisson digunakan dalam melakukan regresi model gravitasi dengan bentuk log linear, sehingga masalah variabel yang dihilangkan pada jarak geografis dapat dihilangkan. Hasil penelitian ini menyimpulkan bahwa korupsi memainkan peran dalam perdagangan internasional melalui mekanisme birokrasi perdagangan dan perizinan investasi dan efek korupsi lebih merugikan eksportir.
\end{abstract}

Kata Kunci: Model Gravitasi, Korupsi, Perdagangan Internasional, Poisson Pseudo Maximum Likelihood (PPML). 


\section{INTRODUCTION}

Corruption is an act that violates a country's legal system and norms. Corruption perception in a country can expand and enter the bureaucratic regulation system in each country, such as bribery and rent-seeking resulting in additional costs to the business. One way to identify the level of corruption is through the existing structures and institutions in a country. The framework of a country's bureaucratic institutions can describe juridical transactions of business practices formally and informally (Cheptea, 2007).

One interesting problem to be investigated is the relationship between bureaucratic institutional framework and trade. There are many aspects of organizational and institutional structure of each country as key factors affecting international trade, such as legal regulations, political systems of business legalization and methods in business (Horsewood \& Voicu, 2012b).

A bureaucratic policy structure and national institutions can affect the ease of conducting business or investment contracts with other countries, because international transactions have different forms of law and political jurisdiction. Many legal functions and bureaucratic policies are designed to complicate business and investment, such as lack of enforcement and protection of business and investment contracts that may cause the investors to be reluctant to conduct business cooperation between countries.

The effect caused by the bad state bureaucracy in terms of trade cooperation with other countries will create risks in the form of additional costs charged to exporters (Anderson \& Marcouiller, 2002). In this case, a bad legal and bureaucratic framework from partner countries can result in the same effect as the imposition of tariffs on imported goods because it can increase costs in cross-border trade. This problem will be responded by exporters by reducing the value of trade with the destination country (Horsewood \& Voicu, 2012).

Direct effect of corruption is very influential on investment, the emergence of corruption will worsen the bureaucracy so that it will have an effect of increased investment cost. Increased corruption will weaken Foreign Direct Investment (FDI). Rodrik (1994) in South Korea and Taiwan, finds that investment is an export determinant.

The increase in a country's investment will be followed by an increase in import of manufactured materials from abroad. This is because the high level of consumption of a country's development is not accompanied by production. Thus, the country imports to meet consumption levels from increased investment activities. The increase in imports due to an increase in investment will cause a reduction in the country's foreign exchange reserves to finance imports. The country will respond to this by making foreign loan If the foreign loan is insufficient, then the export will be increased, so that there is a causality relationship between investment to import and import to export.

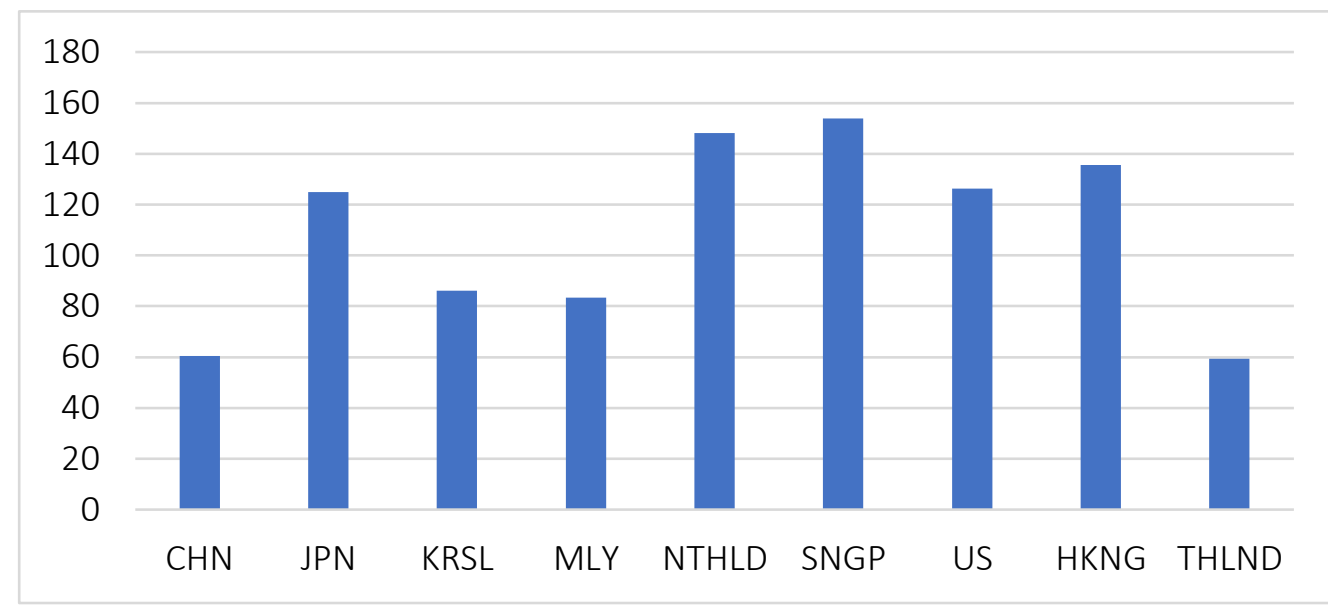

Graph 1. Corruption Perception Index of Nine Countries in 2000-2016

Source: www.transparency.org 
Corruption perception index is an index that measures the level of corruption in a country. Based on index scale of $0-1$, value 0 indicates that the country has a very severe level of corruption, while value 10 indicates that the country is clean from corruption. The transparency international agency conducts a survey and ranks 200 countries in handling corruption every year.

The assessment of transparency agency includes openness of rules, planning, processes and actions. Transparency measures public services, bureaucracy, transparent business that can be accounted for by the reports of its activities. The objective is to maintain public trust in the domestic activities of a country's government.

Indonesia's largest export destination countries are developed countries with high welfare level and good governance. Based on Corruption Perception Index (CPI) of 9 countries above, Singapore has the highest CPI, while China and Thailand have the lowest CPI. CPI can simply show the level of ease of bureaucracy in a country. This is because bad bureaucracy shows a high level of corruption. Bureaucracy is a difficult barrier to cross-border trade (Bandyopadhyay \& Roy, 2007).

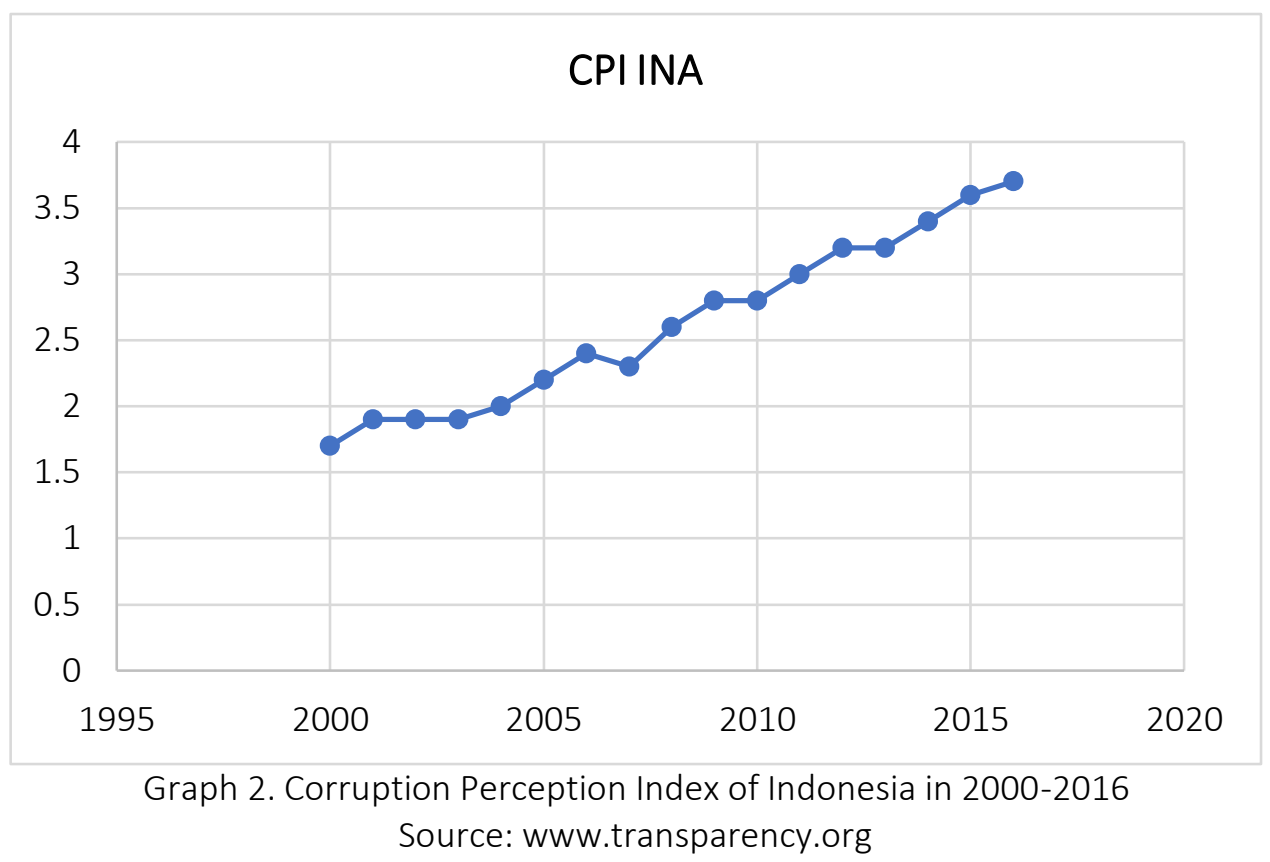

Indonesia is a country in Asia whose CPI values are constantly increasing significantly from 2000 to 2016. This proves that bureaucratic management and corruption eradication in Indonesia continue to improve every year. For this reason, Indonesia is selected in the research on the effect of corruption on international trade.

In measuring the strength of bilateral international trade, the theory often used by researchers such as Benedictis, Santis, \& Vicarelli (2005) and Anderson \& Wincoop(2008) is gravity model. They use gravity model in measuring the strength of trade between countries by using GDP variable and distance as a barrier. With further development, gravity model can be used in measuring the effect of trade barriers such as language, currency and ethnic differences. Based on the above reasons, gravity model is used in this research to measure the effect of corruption on international trade. This theory proves that the strength of international trade has a positive relationship with the country's national income and has a negative relationship with distance or barriers between the capital to the two countries (Voicu \& Horsewood, 2006).

The combination of gravity model with CPI value will explain the factors affecting international trade and the role of corruption in it. Based on this problem, this research focuses on the effect of corruption on international trade by taking a case study of Indonesia's bilateral trade with the 9 largest export destination countries. 


\section{RESEARCH METHOD}

\section{Data and Data Source}

The analytical model used in this research is quantitative method with panel regression from 2000 to 2016. Data of research samples are taken from 9 countries (United States, Netherlands, Japan, South Korea, China, Thailand, Hong Kong, Singapore, Malaysia). Variables data taken are; GDP, population, CPI (Corruption Perception Index) and geographical distance between two national capitals. The sample data were taken from several sources including the World Bank, Transparency International and google map.

\section{Operational Definition of Variables}

The variables are grouped into 2 (two), namely dependent and independent variables. The dependent variable in this research is Export ij = Indonesia's Export Value to 9 destination countries (Thousand USD), while the independent variables in this research are GDP $\mathrm{i}=$ Indonesian GDP (Million USD), GDP $\mathrm{j}=$ GDP of 9 export destination countries (Million USD). GDP is a measure in describing an economic power indicating the production capacity of all goods and services in the country in a certain period of time. GDP is the main point in an estimate that uses gravity model, because it reflects overall demand and supply (Tinbergen Jan, (1965)).

$\mathrm{CPI} \mathrm{i}=$ Corruption Perception Index of Indonesia (Unit), $\mathrm{CPI}$ j = Corruption Perception Index of 9 export destination countries (Unit). CPI is a corruption perception index measured by international transparency institution. CPI has a range of index values from 0 to 10 , the greater index value indicates that the country is increasingly clean from corruption. GDP i/POP $\mathrm{i}=$ Indonesia's population per capita income (Unit), GDP j/POP j = per capita income of 9 export destination countries (Unit). Horsewood \& Voicu, (2012b) explain that per capita income reflects the level of economic independence of a country. Geographical Distance = geographical distance between two national capitals, geographical distance is measured using google map expressed in a unit of kilometer $(\mathrm{Km})$.

\section{Analysis Tool}

The estimation of gravity model with logarithmic transformation will have some problems, especially if there is an observation data with a value of 0 . Value of 0 will occur for several reasons, including the condition of no trade. This will cause errors in the estimation process as the error value will change and the logarithm form of zero will be problematic in estimation. Previous researches have suggested to use Poisson Pseudo Maximum Likelihood (PPML) estimation method when encountering observation problem with zero value (Silva \& Tenreyro, (2006)). They also recommend to use PPML estimator in performing gravity model estimation process with linear-log equation, estimates with various gravity models with PPML will generate better results. The use of PPML method is not only to deal with the condition of the observational data with zero value, but also to deal with estimation results affected by heteroscedasticity problems. Furthermore, the interpretation of PPML is in accordance with OLS estimation even though the dependent variable of PPML is in the form of level. The coefficient of independent variable can be interpreted elastic or semi-elastic, depending on whether the condition of independent variables are in the form of logarithms or not (Shepherd, (2016)). PPML estimation can be written in the following form:

$$
\sum_{i=1}^{n}\left[Y_{i j t}-\exp \left(x_{i j t} \theta\right)\right] x_{i j t}=0
$$

Where $\mathrm{Xijt}$ is an independent variable of gravity model and $\beta$ is a parameter. The econometric parameter can be formulated as follows:

$$
\mathrm{X}_{\mathrm{ij}}=\alpha+\beta_{1} \operatorname{lnGDP}_{\mathrm{i}}+\beta_{2} \operatorname{lnGDP}_{\mathrm{j}}+\beta_{3} \mathrm{CPI}_{\mathrm{i}}+\beta_{4} \mathrm{CPI}_{\mathrm{j}}+\beta_{5} \text { Jarak Geografis }+\frac{\text { GDP } \mathrm{i}}{\text { POP } \mathrm{i}}+\frac{\text { GDP } \mathrm{j}}{\mathrm{POP} j}+\epsilon
$$




\section{RESULT AND DISCUSSION}

\section{The Effect of CPI $i$ and $j$ on Indonesia's Export Value to Nine Destination Countries}

The regression coefficient of Indonesia's CPI variable is 1.407 with positive value and partially, the probability value is $0.0000(0.0000<0.05)$. Thus, it can be concluded that Indonesia's corruption perception index (CPI) variable has a positive and significant effect on Indonesia's export value to 9 destination countries. Corruption perception index (CPI) has a range of 0 to 10 , greater index value indicates that the country is increasingly clean from corruption. Thus, an increase in corruption perception index in Indonesia increases the value of Indonesia's bilateral trade to 9 destination countries. This explains that the effect of corruption is more perceived by exporting countries and the level of corruption of importing countries does not have a significant effect on exporting countries. Based on the result of regression estimation above, it can be concluded that Indonesia's corruption perception index (CPI) accepts $\mathrm{H}_{1}$ and rejects $\mathrm{H}_{0}$, while the corruption perception index of 9 destination countries accepts $\mathrm{H}_{0}$ and rejects $\mathrm{H}_{1}$.

The result of this research supports the previous researches conducted by Pushan Dutt and Daniel Traca (2007), James E Anderson, Douglas Marocouiller (2000), showing that corruption of exporting and importing countries has a significant and negative effect on export. The result obtained in this research is slighly different explaining that corruption of importing countries has no significant effect on Indonesia's export volume. This is because 9 export destinations of Indonesia are countries with a very low level of corruption. Another researches conducted by Anca Monika Voicu, Nicholas Horsewood (2007) (2011) and (2012) on corruption and international trade show that corruption perception index of exporting and importing countries has a positive relationship with the export values of several European countries. The researches of Anca Monika Voicu, Nicholas Horsewood (2006) (2011) and (2012) also show that the effect of corruption is more perceived by exporting countries than importing countries. The results are in accordance with this research that corruption has greater effect on Indonesia as an exporting country. Therefore, if a country will develop trade with other countries, then the bureaucratic system and business ethics must be improved.

\section{The Effect of GDP i (Indonesia) and GDP $\mathrm{j}$ (Nine Indonesia Export Destination Countries) on Indonesia's Export Value to Nine Destination Countries}

The regression coefficient of GDP $\mathrm{i}$ (Indonesia) is 0.040 with positive value and partially, the probability value is $0.556(0.556>0.0000)$. Thus, it can be concluded that GDP i variable has no significant effect on Indonesia's export value to 9 destination countries. While GDP $\mathrm{j}$ variable (9 importing countries) has a negative coefficient $(-0.058)$ and partially has probability value of 0.103 $(0.103>0.05)$, thus GDP $\mathrm{j}$ has no significant effect on Indonesia's export value to 9 destination countries.

The result of this research indicating that there is a positive relationship between Indonesia's GDP and Indonesia's export value to 9 destination countries is supported by previous researches conducted by Pushan Dutt and Daniel Traca (2007), James E Anderson, Douglas Marocouiller (2000), Anca Monika Voicu and Nicholas Horsewood (2006), Nicholas Horsewood and Anca Monika Voicu (2011). In this case, the researcher observed that the increase in Indonesia's GDP triggered an increase in export of goods and services to 9 destination countries (Growth led Export Hypothesis). This hypothesis can be explained because an increase in a country's economic income will encourage an increase in production factors. Increased production factors will cause increased supply of goods and services. Increased supply does not only occur in goods and services for domestic demand, but also supply for exported goods. The other impact of economic improvements is the rapid transfer of technology and innovation in domestic industries. This will then encourage an increase in exports caused by economic growth (Findlay, 1984).

Based on the result, it can be concluded that growth led export occurs in Indonesia. The result of hypothesis in this research indicates that $\left(\mathrm{H}_{1}\right)$ is rejected and $\left(\mathrm{H}_{0}\right)$ is accepted. The result of hypothesis obtained is due to the data limitations used in this research. 


\section{The Effect of GDP i/POP i (Indonesia per Capita Income), GDP j/POP j (per Capita Income of Nine Indonesia Export Destination Countries)}

The regression coefficient of GDP i/POP i variable (Indonesia's per capita income) is insignificant on Indonesia's export value to 9 destination countries. While the regression coefficient of GDP j/POP j (per capita income of 9 countries) is -0.019 with probability value of $0.006(0.006<0.05)$. From the result of probability value of GDP j/POP j, it can be determined that per capita income of 9 importing countries has a negative and significant effect on Indonesia's export value.

It is explained that per capita is used to measure the level of a country's economic independence. The greater per capita income of a country, the lower the country's demand for imported goods. This emphasizes that if a country is more independent, then the country will try to meet all its own domestic needs and reduce the volume of import.

The reason can be explained if the country imports more finished goods than raw or semifinished goods, but importing countries from Indonesia mostly import raw or semi-finished goods such as palm oil, textile/garment, footwear, electronic components and other things. Based on the fact, there is negative relationship between per capita income of 9 importing countries and Indonesia's export value due to the shift of trade relations between Indonesia as an importing country to other countries. Data from OECD (Organization for Economic Co-operation and Development) shows that the United States imports more raw and semi-finished goods such as garments and footwear to India than Indonesia. Moreover, the needs of automotive and electronics industries require Japan to import more semi-finished goods from China. Thus, Indonesia is less competitive in trading with competing countries that have the same commodity causing a decrease in export demand.

The researches conducted by Nicholas Horsewood and Anca Monika Voicu (2011), (2012) also find that there is negative relationship between per capita income and export value. However, the researches conducted by James E Anderson, Douglas Marocouiller (2000) find different result that per capita income has a positive effect on export value of international trade. There are two hypotheses generated from the results of regression above. First, GDP i/POP i variable accepts $\mathrm{H}_{1}$ and rejects $\mathrm{H}_{0}$, while GDP j/POP j variable rejects $\mathrm{H}_{1}$ and accepts $\mathrm{H}_{0}$.

\section{The Effect of Geographical Distance on Indonesia's Export Value to Nine Destination Countries}

The regression coefficient of geographical distance is 0.101 with positive value and partially, the probability value is $0.058(0.058<0.10)$. Thus, it can be concluded that geographical distance variable has a positive and significant effect on Indonesia's export value to 9 destination countries. The result of regression above indicates the hypothesis that is not in accordance with previous researches. The hypothesis rejects ( $\mathrm{H} 1$ ) and accepts ( $\mathrm{HO})$.

The above result contradicts the previous research conducted by Dutt \& Traca, (2007) on corruption and trade. One of the results obtained from their research explains the negative effect of geographical distance on the export value in international trade.

Whereas in the case of research in Indonesia, distance is no longer seen as a trade barrier. The existence of a trade commission in a transaction causes geographical distance to have a positive relationshop with the trade value. Trade commission is carried out by giving special commissions from the third parties to exporters and importers. This trade commission will get greater profit, if the value of international trade transaction increases. 
Table 1. Estimation Results of PPML (Poisson Pseudo Maximum Likelihood)

\begin{tabular}{lccc}
\hline \multirow{2}{*}{ Dependent Variabel: Export ij } & \multicolumn{3}{c}{ PPML } \\
\cline { 2 - 4 } & Coefficient & Standart Error & $\mathrm{p}$ Value \\
\hline CPI i (Indonesia) & 1.407 & 0.213 & 0.000 \\
CPI j (9 export destination countries) & 0.197 & 0.149 & 0.186 \\
GDP i (Indonesia) & 0.040 & 0.068 & 0.556 \\
GDP j (9 export destination countries) & -0.058 & 0.036 & 0.103 \\
GDP i / POP i (Indonesia per capita income) & 0.059 & 0.067 & 0.377 \\
GDP j / POP j (Per capita income of 9 countries) & -0.019 & 0.006 & 0.006 \\
Geographical distance & 0.101 & 0.053 & 0.058 \\
Constant & 5.510 & 2.407 & 0.022 \\
Prob F/Chi2 & 0.000 & & \\
R Sq & 0.25 & & \\
\hline
\end{tabular}

Source: Processed with Stata 14

$$
\begin{aligned}
\text { Export } i j= & 5.510+0.040 \text { GDP } i-0.058 \text { GDP } j+1.407 \text { CPI } i+0.197 \mathrm{CPI} j+0.059 \frac{\text { GDPi }}{\text { POPi }} \\
& -0.019 \frac{\mathrm{GDPj}}{\mathrm{POPj}}+0.101 \text { Geographical Distance }+\mu \mathrm{it}
\end{aligned}
$$

\section{CONCLUSION}

Based on the research conducted on the effect of corruption on international trade (a case study of Indonesian trade to 9 export destination countries), it can be concluded that:

(1) Using gravity model, the coefficient of Indonesia's corruption perception index has a positive relationship on Indonesia's export value to 9 destination countries. Greater corruption perception index reflects that the country is cleaner from corruption. Thus, it can be concluded that corruption plays a role in international trade. The cleaner the country from corruption, the higher the trade value. The form of bureacracy and the model of government administration highly determine the progress of international trade in a country. Different result is obtained from the corruption perception index of 9 importing countries, it has a negative and insignificant relationship on Indonesia's trade value to 9 destination countries. This research obtains the fact that the effect of corruption is more perceived by exporting countries than importing countries.

(2) Indonesia's Gross Domestic Product (GDP i) has a positive and insignificant relationship on Indonesia's trade value to 9 destination countries. This indicates that GDP of exporting countries measures the production capacity and the economic size. However, the increase in Indonesia's GDP cannot increase the trade value between countries. While GDP j (9 importing countries) represents the economic size and the ability of domestic consumption. Thus, it can be concluded that Indonesia's GDP has no effect on export value, so that the hypothesis of Growth led Export in Indonesia from 2000-2016 has not been fulfilled.

(3) Indonesia's per capita income (GDP i/POP i) has a positive and insignificant relationship on Indonesia's export value to 9 destination countries. Per capita income represents the strength of a country's economic self-sufficiency or economic independence. In addition, per capita income measures people's purchasing power. Meanwhile, per capita income of 9 countries (GDP j/POP j) has a negative and significant effect on Indonesia's trade value. The increase in per capita income of 9 countries may not necessarily increase Indonesia's export to these 9 countries. This is due to the fact that most of the commodities exported by Indonesia consist of raw and semi-finished goods. This is due to a shift in public consumption when there is an increase in public's per capita income.

(4) Trade barriers calculated using geographical distance has a positive and significant effect on Indonesia's export value to 9 destination countries. In a dirty bureaucracy, there is a charge 
of trade commission from a transaction. The amount of trade commission will be greater along with the increase in trade value caused by the increase in distance of goods delivery. Thus, trade barrier in the form of geographical distance is no longer seen as an aspect that reduce trade.

Based on the research conducted on the effect of corruption on international trade, a case study of Indonesian trade to 9 destination countries using gravity model approach, the policy suggestions in this research are as follows:

(1) In increasing Indonesia's export, the government should improve institutions and bureaucracy. Efficiency and openness in administration can reduce the possibility of trade commission.

(2) Directorate general of customs and excise as a government institution directly deals with exports and imports, so that the government should supervise the performance of customs and excise agency in supporting healthy international trade.

\section{REFERENCES}

Anderson, J. E., \& Marcouiller, D. (2002). Insecurity and the Pattern of Trade: An Empirical Investigation. The Review of Economics and Statistics, 84(2), 342-352.

Anderson, J. E., \& Wincoop, E. Van. (2008). Gravity with Gravitas: A Solution to the Border Puzzle. The American Economic Review, 93(1), 170-192.

Bandyopadhyay, S., \& Roy, S. (2007). Corruption and Trade Protection: Evidence from Panel Data. Research Division Federal Reserve Bank of St. Louis Working Paper Series Corruption.

Benedictis, L. De, Santis, R. De, \& Vicarelli, C. (2005). Hub and Spoke or else? Free trade agreements in the enlarged European Union. The European Journal of Comparative Economics, 2, 245-260.

Cheptea, A. (2007). Trade liberalization and institutional reforms. Economics of Transition, 15(2), 211-255.

Dutt, P., \& Traca, D. (2007). Corruption and Bilateral Trade Flows : Extortion or Evasion ? INSEAD, 37.

Findlay, R. (1984). Chapter 4 Growth and development in trade models. Sciencedirect, 1(C), 185-236. https://doi.org/10.1016/S1573-4404(84)01007-8

Horsewood, N., \& Voicu, A. M. (2012a). Does Corruption Facilitate Trade for the New EU Members? Economics, (2011).

Horsewood, N., \& Voicu, A. M. (2012b). Does Corruption Hinder Trade for the New EU Members? Economics, 6, 0-29.

Rodrik, D. (1995). Getting interventions right : how South Korea and Taiwan grew rich. NBER Working Papers from National Bureau of Economic Research, Inc.

Shepherd, B. (2016). The Gravity Model of International Trade: A User Guide (An updated version). United Nations publication (Economics and Social Commission for The Asia and Pasific). Retrieved from http://www.unescap.org/sites/default/files/GravityUserGuide-REVISED-02.pdf

Silva, J. M. C. S., \& Tenreyro, S. (2006). THE LOG OF GRAVITY. The MIT Press Journals, 88(November), 641-658.

Tinbergen (Jan). (1965). Shaping the world economy. Suggestions for an international economic policy. Revue Économiqueo, 16(5), 840-840.

Voicu, A. M., \& Horsewood, N. (2006). European Trade Study Group Vienna 2006 Gravity and Trade Effects of Regional Trading Arrangements : The Central-Eastern European Experience. European Trade Study Group, 1-25.

http://www.kemendag.go.id/id/economic-profile/indonesia-export-import

https://data.worldbank.org/?locations=US-SG-KR-MY-NL-TH-CN-JP-HK

https://www.bps.go.id/publication/2017/12/29/ff0b35badbf7382f549d3204/buletin-statistikperdagangan-luar-negeri-ekspor-menurut-komoditi-hs--oktober-2017.html

https://www.oecd-ilibrary.org/trade/international-trade-by-commodity-statistics/volume2018/issue-3_itcs-v2018-3-en 